\title{
EROSÃO CAUSADA PELA PRÁTICA DO MONTANHISMO NA TRILHA PARA OS PICOS CAMAPUÃ E TUCUM - CAMPINA GRANDE DO SUL (PR)
}

\author{
Yury Vashchenko*, Daniela Biondi**, Nerilde Favaretto*** \\ *Eng. Florestal, M.Sc., Doutorando em Engenharia Florestal, UFPR - vashchenko_01@yahoo.com.br \\ **Eng ${ }^{a}$. Florestal, Dr ${ }^{\mathrm{a}}$., Depto. de Ciências Florestais, UFPR - dbiondi@ufpr.br \\ ***Enga . Agrônoma, Ph.D., Depto. de Solos e Engenharia Agrícola, UFPR - nfavaretto@ufpr.br \\ Recebido para publicação: 22/09/2006 - Aceito para publicação: 17/09/2007
}

\begin{abstract}
Resumo
O objetivo deste trabalho foi avaliar a erosão causada pela prática do montanhismo na trilha para os picos Camapuã e Tucum, em Campina Grande do Sul (PR). A intensidade de uso foi obtida através de entrevistas. A trilha foi mapeada, utilizando-se um GPS, e dividida em quatro trechos, nos quais se avaliaram a declividade, a profundidade, a largura e a extensão, o tipo de cobertura do solo, a formação de degraus e sulcos e a exposição do solo, raízes e rochas. A intensidade de erosão foi calculada considerando os fatores profundidade do leito e formação de degraus ou sulcos. A trilha apresentou intensidades de uso diferentes, sendo que o número de passagens de visitantes estimado foi igual a 1023, 868, 711 e 141 nos trechos $01,02,03$ e 04, respectivamente. A intensidade de erosão variou em função da intensidade de uso, declividade, cobertura vegetal e classe de solo, sendo classificada de muito baixa a muito alta, conforme aumentou a intensidade de uso e a declividade. A vegetação diminui a intensidade de erosão, porém esse efeito diminui com o aumento da intensidade de uso e da declividade.

Palavras-chave: Declividade; intensidade de uso; formação de sulcos; cobertura vegetal; degradação do solo.
\end{abstract}

\begin{abstract}
Erosion caused by climbing mountain practice on the trail to Camapuã and Tucum peaks - Campina Grande do Sul (PR). The objective of this work was to evaluate the erosion caused by climbing mountain practice on the trail to Camapuã and Tucum peaks - Campina Grande do Sul (PR). The use intensity was obtained through interviews. The trail, divided in four sections, was delimited using a GPS. In each section it was evaluated the slope, depth, width, and extension of the trail as well as the type of soil covering, the formation of steps and rill erosion and the exposition of the soil, root, and rock. The erosion intensity in the trail was calculated considering the depth of the trial and the formation of steps or rill erosion. The trail presents different use intensity, it was estimated the walked by number was $1023,868,711$ and 141 in section $01,02,03$ and 04 , respectively. The erosion intensity was modified with the use intensity, slope, vegetal covering and soil class. It was classified of very low to very high, according with the increase of the use intensity and slope. The vegetation decreases the erosion intensity. However this effect decreases with the increase of the use intensity and slope.

Keywords: Slope; use intensity; rills formation; vegetal covering; soil degradation.
\end{abstract}

\section{INTRODUÇ̃̃o}

A busca cada vez maior pela natureza está dando impulso ao turismo em áreas silvestres, que, dependendo das atividades praticadas, pode ser chamado de ecoturismo, turismo de aventura, turismo rural, histórico-cultural ou técnico-científico. As atividades em regiões montanhosas fazem parte do turismo de aventura e são denominadas de montanhismo, o qual consiste em alcançar os cumes das montanhas por meio de escaladas ou caminhadas (SEMA, 1996; SEMA, 2000). 
A prática do montanhismo envolve a formação de trilhas, as quais passam pelas mais diversas situações de relevo, solo e vegetação. A pressão exercida pela prática de caminhadas causa um impacto diferenciado, dependendo da condição existente. Por exemplo, algumas plantas são mais resistentes ao pisoteio que outras, e solos menos desenvolvidos resistem menos ao processo de compactação e à erosão.

A ocorrência de impactos em áreas naturais é conseqüência do uso, seja ele realizado com objetivos educacionais ou recreativos, sendo que todos os visitantes, inclusive os mais conscientes, deixam pegadas (BARROS, 2003).

A primeira conseqüência na formação de uma trilha é a eliminação da cobertura vegetal que protege o solo do impacto direto das gotas da chuva e do escoamento superficial, podendo dar início a um processo erosivo.

A erosão é um processo que causa graves problemas em áreas onde existem trilhas, principalmente em regiões montanhosas. A erosão depende do tipo de solo, da topografia, do padrão de drenagem da área e da cobertura vegetal (ANDRADE, 2003).

Solos ricos em matéria orgânica são menos vulneráveis à erosão, devido à melhor drenagem (maior grau de estruturação) e por propiciar um melhor crescimento de plantas. No entanto, quando o pisoteio é freqüente, o solo é compactado e a matéria fragmentada, aumentando a suscetibilidade à erosão. Isso faz com que os horizontes subsuperficiais fiquem expostos, bem como reduz o banco de sementes do solo e, conseqüentemente, a propagação das plantas (MAGRO, 1999).

A vegetação na superfície das trilhas limita a ação erosiva das gotas da chuva sobre o solo, interceptando-as e diminuindo a enxurrada. Porém o pisoteio elimina essa vegetação, deixando o solo exposto e sem obstáculos, o que facilita a formação de enxurrada e erosão (TROEH et al., 1999).

No estado do Paraná, entre os locais mais procurados para a prática do montanhismo, na Serra do Mar, destaca-se a área que compreende os picos Camacuã, Camapuã e Tucum, os quais possuem $1.550 \mathrm{~m}$, $1.706 \mathrm{~m}$ e $1.736 \mathrm{~m}$ de altitude, respectivamente (BRASIL, 1971; IBGE, 1992a). Possuem, ainda, uma característica muito peculiar: seus cumes são arredondados, com afloramento de rochas e cobertos por vegetação herbácea, os chamados campos de altitude.

$\mathrm{Na}$ trilha que leva para os picos Camapuã e Tucum, observa-se um processo erosivo muito acelerado nos trechos mais freqüentados, principalmente sob os campos de altitude, enquanto que nos trechos menos freqüentados não se observa esse processo, sendo, portanto um local propício para realizar um estudo sobre a erosão causada pela prática do montanhismo e os fatores que a influenciam.

Assim, o objetivo geral deste trabalho foi avaliar a erosão causada pela prática do montanhismo na trilha para os picos Camapuã e Tucum, em Campina Grande do Sul (PR), cujos objetivos específicos foram:

- caracterizar a intensidade de uso, as condições físicas da trilha e a intensidade de erosão; e

- relacionar a intensidade de erosão com a intensidade de uso, vegetação, solo e declividade.

\section{MATERIAL E MÉTODOS}

\section{Caracterização da área de estudo}

A Serra do Mar constitui um sistema montanhoso que se estende desde o Espírito Santo até o sul de Santa Catarina. No estado do Paraná, é a zona limítrofe entre o litoral e o primeiro planalto, formando serras marginais descontínuas, que se elevam de $500 \mathrm{~m}$ a $900 \mathrm{~m}$ acima do nível do planalto, sendo mais escarpada do lado do Atlântico que do continental e dotada de taludes íngremes e vertentes vigorosas (BIGARELLA, 1978).

A área de estudo localiza-se no estado do Paraná, na parte da Serra do Mar que compõe a Área Especial de Interesse Turístico (AEIT) do Marumbi (criada pela Lei Estadual 7.919, de 22 de outubro de 1984), a qual engloba diversas serras. Nos municípios de Antonina e Campina Grande do Sul está localizada a Serra Ibitiraquire ("Serra Verde", em tupi). Na parte que compreende o município de Campina Grande do Sul, na localidade denominada Terra Boa (entre as coordenadas $712.000 \mathrm{~m}$ e 718.000 $\mathrm{m}$ W e 7.203.500 m e 7.206.500 m S no sistema UTM, Fuso 22 sul, Meridiano Central 51 $01^{\circ}$ '00”), estão localizados os picos Camapuã e Tucum, componentes do Parque Estadual do Pico Paraná, criado pelo Decreto Estadual 7.300, de 24 de setembro de 1990 (Figura 1). O acesso a esses picos é feito pela rodovia BR-116, saindo-se de Curitiba e percorrendo aproximadamente $50 \mathrm{~km}$ até a localidade de Terra Boa, onde 
se percorrem cerca de $5 \mathrm{~km}$ em uma estrada de terra que leva a uma chácara (chácara do Milani), onde a trilha de acesso aos picos tem início.

A trilha percorre o vale do ribeirão Samambaia, acompanhando suas margens, no sentido sudeste, cruzando-o seis vezes sendo que em uma parte do percurso o leito da trilha se torna o próprio leito do Samambaia (trecho 01). Chegando à parte mais alta do vale do ribeirão Samambaia, a trilha se bifurca: seguindo em frente, chega-se no pico Ciririca, enquanto que, tomando a esquerda, subindo pela face sul, acompanhando o divisor de águas (parte mais alta do relevo que separa dois rios), chega-se no pico Camapuã (trecho 02). Seguindo para sudeste a partir do pico Camapuã e acompanhando outro divisor de águas, chega-se no pico Tucum (trecho 03). A partir daí, acompanhando um outro divisor com sentido nordeste (trecho 04), chega-se no vale do rio do Meio, ponto considerado o final da trilha (para o estudo). Seguindo em frente, chega-se no pico Cerro Verde.

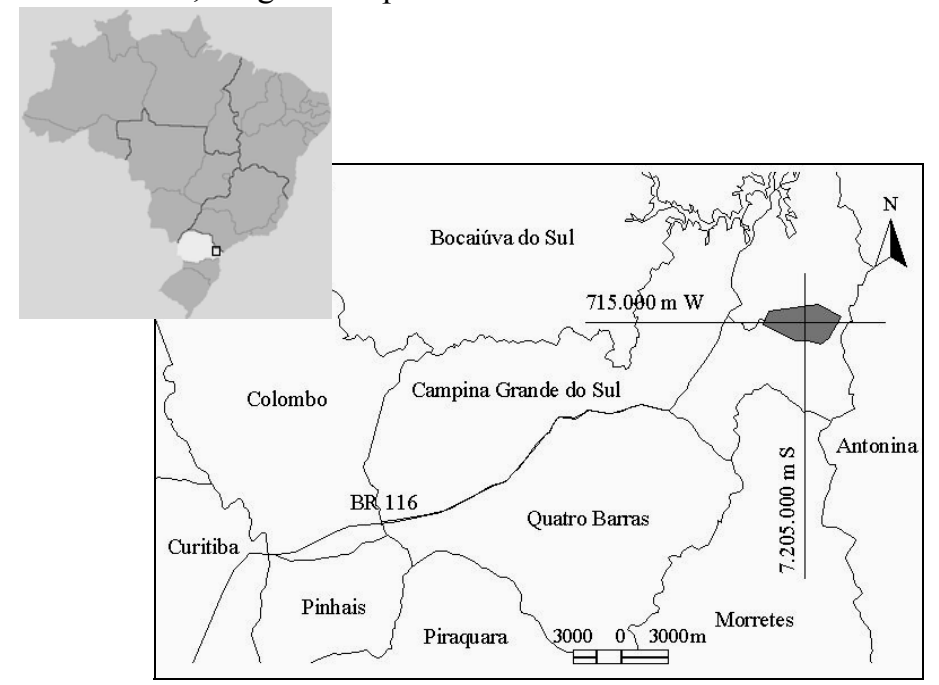

Figura 1. Localização da área de estudo.

Figure 1. Localization of the study area.

A área de estudo encontra-se sobre um bloco granítico constituído pelo Granito Graciosa, rocha intrusiva originada há mais de 600 milhões de anos, no Pré-Cambriano. Esse granito exibe sempre cores claras (branco, cinza claro, creme ou tom levemente avermelhado). Esse bloco granítico é retalhado por sistemas de fendas, diáclases e falhamentos (CORDANI; GIRARDI, 1967).

Segundo a classificação de Köppen, o clima da região é temperado $(\mathrm{Cfb})$, caracterizado por temperatura média no mês mais frio abaixo de $18{ }^{\circ} \mathrm{C}$ (mesotérmico), com verões frescos, temperatura média no mês mais quente abaixo de $22{ }^{\circ} \mathrm{C}$ e sem estação seca definida (IAPAR, 1994).

$\mathrm{Na}$ área de estudo, ocorrem cinco classes de solo, sendo três pertencentes ao grupamento dos Neossolos e dois ao grupamento dos Cambissolos: Cambissolo Háplico Ta Distrófico lítico, Cambissolo Háplico Ta Distrófico léptico, Neossolo Litólico Húmico típico, Neossolo Litólico Distrófico típico e Neossolo Litólico Hístico típico. A profundidade dos Neossolos chega até $25 \mathrm{~cm}$, enquanto que a dos Cambissolos chega a ultrapassar os $50 \mathrm{~cm}$. A profundidade dos horizontes em cada solo oscila muito, em alguns pontos passando de $20 \mathrm{~cm}$, e em outros sendo menor que $10 \mathrm{~cm}$. Isso possivelmente ocorre devido ao relevo e à precipitação abundante, fatores que interferem na formação do solo (VASHCHENKO, 2006).

Considerando a cobertura vegetal, a área de estudo é coberta por duas florestas distintas, a Floresta Ombrófila Densa, também conhecida como Floresta Atlântica, e a Floresta Ombrófila Mista, também conhecida como Floresta com Araucária, sendo que ocorre apenas a formação Montana na Floresta Ombrófila Mista e as formações Montana e Altomontana na Floresta Ombrófila Densa. Além das Florestas Ombrófila Densa e Mista, a área ainda apresenta os Refúgios Vegetacionais, os quais estão localizados nos topos e áreas com vegetação secundária, que ocorrem principalmente no vale do ribeirão Samambaia. Ocorre uma alta relação entre o solo e a vegetação, sendo que a vegetação, possivelmente, seja reflexo das classes de solo existentes. Sobre o Neossolo Litólico Hístico típico encontram-se os 
Refúgios Vegetacionais (campos de altitude), enquanto que sobre Neossolo Litólico Distrófico típico (com inclusões Neossolo Litólico Húmico) encontra-se a Floresta Ombrófila Densa Altomontana. A Floresta Ombrófila Densa Montana e a Floresta Ombrófila Mista Montana encontram-se sob o Cambissolo Háplico Ta Distrófico léptico (com inclusões do Neossolo Litólico Húmico) e sob Cambissolo Háplico Ta Distrófico lítico, respectivamente (VASHCHENKO, 2006).

\section{Intensidade de uso}

A intensidade de uso (número de freqüentadores) foi avaliada através de entrevistas de uma a duas vezes por mês durante o período de um ano. Os dias para a realização das entrevistas foram escolhidos aleatoriamente, e o tempo de permanência para a realização das entrevistas variou de dois a três dias, sendo um dia de semana e um ou dois dias de final de semana ou feriado.

As entrevistas foram referentes ao roteiro utilizado pelos montanhistas e a quantas vezes o grupo passou em cada trecho, podendo ser duas vezes, quando ida e volta pelo mesmo caminho, ou uma vez, quando da tomada de um caminho para ida e de outro para volta.

A partir dessas entrevistas, foi determinado o número de passagens de visitantes em cada trecho em cada dia da semana (sábado, domingo, feriado e dia útil). Obteve-se a média de passagens para cada dia da semana dividindo-se o número total de passagem ocorrido em um determinado dia (sábado, domingo, feriado ou dia útil) pelo número total desse dia em que houve entrevista. $\mathrm{O}$ valor do número de passagens de visitantes anual para cada dia da semana foi obtido multiplicando-se a média de passagens para cada dia com o número total de dias ocorridos durante um ano (dezembro de 2004 a novembro de 2005). O número anual de passagem por trecho foi obtido somando-se o número de passagens anual dos dias da semana do trecho correspondente.

\section{Mapeamento e caracterização da trilha \\ Mapeamento da trilha}

A trilha foi mapeada utilizando-se um GPS da marca Garmim, modelo Etrex Vista, com a configuração "South America 69", correspondente ao datum SAD-69, que forneceu as coordenadas geográficas em latitude e longitude. As coordenadas obtidas sob floresta tiveram a precisão média de $20 \mathrm{~m}$, enquanto as coordenadas obtidas sob campo (Refúgio Vegetacional) tiveram uma precisão média de $8 \mathrm{~m}$.

Os dados obtidos com o GPS foram acessados no programa "GPS Track Maker PRO 3.7”, no qual as coordenadas geográficas foram convertidas em coordenadas UTM em metros. No programa "ArcView GIS 3.2", os pontos obtidos com o GPS deram origem ao traçado da trilha.

\section{Caracterização da trilha}

Para a caracterização da trilha, ela foi dividida por trecho, sendo cada trecho subdividido por vegetação atual, classe de solo e declividade média. Optou-se por declividade média devido à oscilação da declividade na superfície da trilha (microrrelevo). Em cada ponto onde se verificou a alteração da declividade média, obtiveram-se as coordenadas geográficas com o GPS. Em cada segmento definido pela declividade média, foram descritos o tipo de cobertura do solo, a formação de degraus, a formação de sulcos, a exposição do solo, de raízes e de rochas na superfície do leito e foram medidas a profundidade, a largura e a extensão. A descrição da trilha foi realizada visualmente, como segue:

a) Vegetação atual

A vegetação atual foi reconhecida conforme Vashchenko (2006), sendo a vegetação nativa e a secundária classificadas de acordo com IBGE (1992b) e SEMA (1998), respectivamente.

b) Classe de solo

As classes de solo foram identificadas segundo Vashchenko (2006), as quais foram classificadas conforme EMBRAPA (1999).

c) Declividade

A declividade foi obtida através do clinômetro.

d) Tipo da cobertura do solo na superfície do leito

O tipo de cobertura do solo na superfície do leito foi classificado conforme o tipo de material vegetal sobre o leito da trilha: serapilheira, quando matéria morta (folhas, galhos, etc.), a qual ocorreu sob floresta, ou vegetação, quando plantas vivas, a qual ocorreu sob campo de altitude (Refúgio Vegetacional).

e) Profundidade e largura da trilha 
A profundidade foi considerada como a diferença de altura (em centímetros) entre o ponto mais baixo e o ponto mais alto do leito da trilha. A largura foi considerada como a distância (em centímetros) entre as margens do leito da trilha. Ambas foram determinadas com uma trena.

f) Extensão da trilha

A extensão (em metros) aproximada da trilha e de cada segmento foi obtida com a utilização do programa ArcView GIS 3.2, medindo-se a distância entre os pontos obtidos com o GPS, os quais deram origem ao traçado da trilha.

g) Exposição do solo na superfície do leito

A exposição do solo na superfície do leito da trilha foi considerada como conseqüência da eliminação da cobertura do solo (serapilheira, quando sob floresta, ou vegetação, quando sob campo de altitude), causada pela ação do pisoteio, e foi classificada como nenhuma, rara, pouca ou muita, as quais correspondem a $0 \%, 1$ a $10 \%, 11$ a $50 \%$ e $>50 \%$ da extensão avaliada com solo exposto.

h) Exposição de raízes na superfície do leito

A exposição de raízes de espécies arbóreas na superfície da trilha foi considerada como conseqüência do aumento da profundidade do leito da trilha, devido à perda de solo causada pelo pisoteio, erosão ou pela ação de ambos, e foi classificada como nenhuma, rara, pouca ou muita, as quais correspondem a $0 \%, 1$ a $10 \%, 11$ a $50 \%$ e $>50 \%$ da extensão avaliada com raízes expostas.

i) Exposição de rochas na superfície do leito

A exposição de rochas na superfície do leito foi considerada como conseqüência da perda total do solo na trilha, causada pela ação de enxurrada (erosão), e foi classificada como nenhuma, rara, pouca ou muita, as quais correspondem a $0 \%, 1$ a $10 \%, 11$ a $50 \%$ e $>50 \%$ da extensão avaliada com rocha exposta.

j) Formação de degraus

A expressão formação de degraus foi utilizada para representar a trilha quando ela apresentava um aspecto parecido ao de uma escada. Essa característica é conseqüência, principalmente, do pisoteio aliado à declividade, que causa alteração do microrrelevo da trilha, podendo ser, também, conseqüência da exposição de raízes ou rochas. A formação de degraus foi classificada como ausente, quando não observado nenhum degrau, pouco presente, quando observados degraus ocasionais, e muito presente, quando observados degraus contínuos em todo o segmento avaliado.

1) Formação de sulcos

A descrição de sulco foi usada quando visualmente pôde ser constatado que o aprofundamento do leito foi conseqüência de enxurradas, sendo observada esta ocorrência nas maiores declividades. A formação de sulcos foi classificada como ausente, quando não observado nenhum sulco, pouco presente, quando observados sulcos ocasionais, e muito presente, quando observados sulcos contínuos em todo o segmento.

\section{Intensidade de erosão}

Após caracterizar a trilha e analisar a formação de degraus e sulcos e a profundidade do leito, exposição de solo, raízes e rochas na trilha nas diferentes classes de vegetação, solo e declividade, optouse por elaborar um método para avaliar a erosão qualitativamente, devido à impossibilidade de implantar um método quantitativo, como, por exemplo, utilização de caixa de contenção de sedimentos ou medição de seção transversal da trilha, ambas usadas para obter a perda de solo durante um determinado período. Esses métodos poderiam não representar todas as situações encontradas na trilha e seriam muito trabalhosos e demorados. Portanto, elaborou-se a classificação da intensidade de erosão da tabela 1, utilizando-se os seguintes parâmetros: formação de degraus, formação de sulcos e profundidade do leito da trilha, considerados os principais indicadores de erosão na trilha.

Os parâmetros utilizados na obtenção da intensidade de erosão receberam valores de impacto de 1 a 5 , de acordo com a tabela 1 . O valor de intensidade de erosão foi obtido pela média aritmética dos valores de impacto referentes a esses parâmetros, gerando as classes de intensidade de erosão, as quais variam de 1 (muito baixa) a 5 (muito alta) (Tabela 1).

Na classe muito baixa (1), não ocorre a formação de degraus ou sulcos, enquanto que nas classes baixa (2) e média (3) ocorre a formação de degraus sem a formação de sulcos. Nas classes alta (4) e muito alta (5), ocorre a formação de sulcos com ou sem a formação de degraus. Considera-se que a classe muito baixa representa o início do processo erosivo, porém não havendo a formação de degraus ou sulcos. Já a classe baixa representa uma fase inicial da formação dos degraus, enquanto que na classe média os degraus estão estabelecidos em toda a extensão do segmento da trilha avaliado. Na classe alta, os degraus 
estão sendo substituídos por sulcos ou os sulcos estão surgindo sem a pré-existência dos degraus, e na classe muito alta os sulcos estão estabelecidos em quase toda a extensão do segmento da trilha avaliado, podendo haver a presença de degraus, devido à exposição de raízes ou rochas em conseqüência da formação dos sulcos.

Tabela 1. Valores do impacto para os parâmetros formação de degraus e de sulcos, profundidade do leito da trilha e classes de intensidade de erosão na trilha para os picos Camapuã e Tucum.

Table 1. Impact values to the stairs and rills formation and trail depth and erosion intensity class in the trail to Camapuã and Tucum peaks.

\begin{tabular}{lcccccc}
\hline Formação de degraus & $\begin{array}{c}\text { Formação de } \\
\text { sulcos }\end{array}$ & $\begin{array}{c}\text { Valor de } \\
\text { impacto* }\end{array}$ & $\begin{array}{c}\text { Profundidade } \\
\text { (cm) }\end{array}$ & $\begin{array}{c}\text { Valor de } \\
\text { impacto }\end{array}$ & Classe & Valor \\
\hline $\begin{array}{l}\text { Ausente } \\
\text { Pouco presente }\end{array}$ & ausente & 1 & 0 a 5 & 1 & Muito Baixa & 1 \\
$\begin{array}{l}\text { Muito presente } \\
\begin{array}{l}\text { Ausente, pouco ou muito } \\
\text { presente }\end{array}\end{array}$ & 2 & 0 a 10 & 2 & Baixa & 2 \\
$\begin{array}{l}\text { Ausente ou pouco } \\
\text { presente }\end{array}$ & pouco presente & 4 & 0 a 15 & 3 & Média & 3 \\
& muito presente & 5 & 0 a 20 & 4 & Alta & 4 \\
\end{tabular}

* O valor de impacto é definido pela combinação entre a formação de degraus e de sulcos, sendo que a formação de sulcos prevalece sobre a formação de degraus.

Em todas as classes de intensidade de erosão, pode ocorrer o aprofundamento do leito, o qual pode ser conseqüência do pisoteio, da ação de enxurrada ou da combinação de ambos. Observa-se que na formação de degraus não ocorre o aprofundamento do leito, portanto a altura dos degraus representa o parâmetro profundidade do leito.

Considerando que os solos mais profundos possuíam espessura de aproximadamente $50 \mathrm{~cm}$, definiram-se as classes profundidades de 0 a $5 \mathrm{~cm}, 0$ a $10 \mathrm{~cm}, 0$ a $15 \mathrm{~cm}, 0$ a $20 \mathrm{~cm}$ e $0>20 \mathrm{~cm}$, com os valores de impacto $1,2,3,4$ e 5 , respectivamente (Tabela 1), pois a profundidade de $5 \mathrm{~cm}$ do leito da trilha em um solo com $25 \mathrm{~cm}$ de espessura representaria uma perda $20 \%$ de solo, por exemplo.

Para o enquadramento de um segmento de trilha em uma das classes de profundidade (Tabela 1), adota-se a maior profundidade encontrada. Por exemplo, um segmento com a maior profundidade igual a $13 \mathrm{~cm}$ foi enquadrado na classe 0 a $15 \mathrm{~cm}$.

\section{Relação entre a intensidade de erosão e a intensidade de uso, a formação vegetal, a classe de solo e a declividade}

Para discutir a relação entre intensidade de erosão, intensidade de uso, formação vegetal, classe de solo e declividade, elaborou-se uma tabela, na qual foram indicadas as respectivas classes observadas em campo. A interpretação desses dados foi baseada na comparação entre os valores de intensidade de erosão correspondentes a cada declividade, classe de solo, formação vegetal e número de visitantes (intensidade de uso).

\section{RESULTADOS E DISCUSSÃO}

\section{Intensidade de uso}

Observou-se que cada trecho da trilha teve uma intensidade de uso diferente, sendo decrescente do trecho 01 para o trecho 04 . No trecho 01 , o mais freqüentado, foram estimadas 1023 passagens, enquanto no trecho 02 foram 868, no trecho 03 foram 711 e apenas 141 passagens no trecho 04 (Tabela 2).

\section{Caracterização geral da trilha}

A trilha foi dividida em quatro trechos, de acordo com a intensidade de uso, e subdividida por vegetação, solo e declividade, para possibilitar a comparação dos dados (Tabela 3). O traçado da trilha pode ser observado na figura 2 , a qual também apresenta a cobertura vegetal atual. 
Tabela 2. Número total e estimado para um ano de passagem de visitantes em cada trecho da trilha para os picos Camapuã e Tucum.

Table 2. Total and estimed number of the visitors passes to one year period in each trail section to the Camapuã and Tucum peaks.

\begin{tabular}{lcc}
\hline Trecho & $\begin{array}{c}\text { Número de passagens nos } \\
\text { dias avaliados }\end{array}$ & Estimativa da passagem anual \\
\hline 1 & 215 & 1023 \\
2 & 199 & 868 \\
3 & 142 & 711 \\
4 & 19 & 141 \\
\hline
\end{tabular}

A seguir serão apresentadas as principais características observadas, a intensidade de uso e a intensidade de erosão em cada trecho da trilha (Tabela 3).

Tabela 3. Intensidade de uso, vegetação atual, solo, declividade, largura, cobertura do solo, exposição de solo, raiz e rocha, formação de degraus e sulcos, intensidade de erosão e extensão observadas na trilha para os picos Camapuã e Tucum.

Table 3. Use intensity, vegetation, soil, slope, width, soil cover, soil, root and rock exposition, steps and rill formation, erosion intensity and extension observed in the trail to Camapuã and Tucum peaks.

\begin{tabular}{|c|c|c|c|c|c|c|c|c|c|c|c|c|c|c|c|}
\hline \multirow{3}{*}{$\begin{array}{l}\text { Trecho }\left(n^{0} \text { de }\right. \\
\text { passagem) }\end{array}$} & \multirow{3}{*}{ Vegetação atual } & \multirow{3}{*}{ Solo } & \multirow{3}{*}{$\begin{array}{c}\text { D } \\
(\%)\end{array}$} & \multirow{3}{*}{$\begin{array}{c}\mathrm{L} \\
(\mathrm{cm})\end{array}$} & \multirow{3}{*}{ CS } & \multicolumn{3}{|c|}{ Exposição } & \multirow{3}{*}{ FD } & \multirow{3}{*}{ FS } & \multirow{3}{*}{$\begin{array}{c}\text { Prof. do } \\
\text { leito (cm) }\end{array}$} & \multicolumn{3}{|c|}{ Intensidade de erosão } & \multirow{3}{*}{$\begin{array}{l}\text { Extensão } \\
\text { (m) }\end{array}$} \\
\hline & & & & & & & & & & & & Valor de & npacto & & \\
\hline & & & & & & So & $\mathbf{R a}$ & Ro & & & & $\begin{array}{l}\text { Degraus } \\
\text { e sulcos }\end{array}$ & Prof. & Valor & \\
\hline \multirow{14}{*}{$\begin{array}{l}1 \\
(1023)\end{array}$} & FOMM & CXvd lítico & 12 & \multirow{14}{*}{50} & & $\mathrm{r}$ & $\mathrm{r}$ & $\mathrm{r}$ & $\mathrm{a}$ & $\mathrm{a}$ & 0 a 5 & 1 & 1 & 1 & 223 \\
\hline & \multirow{5}{*}{ FODM } & \multirow{2}{*}{ CXvd léptico } & 10 & & & $\mathrm{n}$ & $\mathrm{r}$ & $\mathrm{r}$ & $\mathrm{a}$ & $\mathrm{a}$ & 0 a 5 & 1 & 1 & 1 & 338 \\
\hline & & & 35 & & & $\mathrm{n}$ & $\mathrm{r}$ & $\mathrm{r}$ & $\mathrm{a}$ & $\mathrm{a}$ & 0 a 15 & 1 & 3 & 2 & 86 \\
\hline & & \multirow{2}{*}{ RLh } & 23 & & & $\mathrm{n}$ & $\mathrm{r}$ & $\mathrm{n}$ & $\mathrm{a}$ & $\mathrm{a}$ & 0 a 5 & 1 & 1 & 1 & 195 \\
\hline & & & 19 & & & $\mathrm{n}$ & $\mathrm{r}$ & $\mathrm{n}$ & a & a & 0 a 5 & 1 & 1 & 1 & 149 \\
\hline & & CXvd léptico & 35 & & & $\mathrm{n}$ & $\mathrm{r}$ & $\mathrm{r}$ & $\mathrm{a}$ & $\mathrm{a}$ & 0 a 5 & 1 & 1 & 1 & 146 \\
\hline & \multirow{6}{*}{ FODA (SSInt) } & \multirow{2}{*}{ RLd } & 4 & & $s$ & $\mathrm{n}$ & $\mathrm{r}$ & $\mathrm{n}$ & $\mathrm{a}$ & $\mathrm{a}$ & 0 a 25 & 1 & 5 & 3 & 118 \\
\hline & & & 34 & & $\mathrm{~s}$ & $\mathrm{n}$ & $\mathrm{p}$ & $\mathrm{n}$ & $\mathrm{mp}$ & $\mathrm{a}$ & 0 a 50 & 3 & 5 & 4 & 51 \\
\hline & & & 1 & & & & $\mathrm{r}$ & & $\mathrm{a}$ & $\mathrm{a}$ & 0 a 5 & 1 & 1 & 1 & 91 \\
\hline & & & 23 & & & $n$ & $\mathrm{r}$ & $n$ & $\mathrm{mp}$ & $\mathrm{a}$ & 0 a 5 & 3 & 1 & 2 & 93 \\
\hline & & RIb & 35 & & & $\mathrm{n}$ & $\mathrm{r}$ & $\mathrm{n}$ & $\mathrm{mp}$ & $\mathrm{pp}$ & 0 a 25 & 4 & 5 & 5 & 163 \\
\hline & & KLn & 35 & & & & $\mathrm{r}$ & & $\mathrm{mp}$ & $\mathrm{pp}$ & 0 a 50 & 4 & 5 & 5 & 111 \\
\hline & & & 17 & & & $\mathrm{n}$ & $\mathrm{r}$ & $\mathrm{n}$ & $\mathrm{a}$ & $\mathrm{a}$ & 0 a 5 & 1 & 1 & 1 & 33 \\
\hline & FODA (SSI) & & 0 & & & $\mathrm{n}$ & $\mathrm{r}$ & $\mathrm{n}$ & $\mathrm{a}$ & $\mathrm{a}$ & 0 a 5 & 1 & 1 & 1 & 89 \\
\hline & & & 35 & & & & $\mathrm{~m}$ & & $\mathrm{mp}$ & & 0 a 20 & 3 & 4 & 4 & 59 \\
\hline & & & 70 & & & & $\mathrm{~m}$ & & $\mathrm{mp}$ & & 0 a 50 & 3 & 5 & 4 & 72 \\
\hline & FODA (SSInt) & & 35 & & & $n$ & $\mathrm{~m}$ & $n$ & $\mathrm{mp}$ & $a$ & 0 a 20 & 3 & 4 & 4 & 97 \\
\hline & FODA (SSInt) & PId & 3 & 50 & & $\mathrm{n}$ & $\mathrm{p}$ & $\mathrm{n}$ & $\mathrm{a}$ & $\mathrm{a}$ & 0 a 15 & 1 & 3 & 2 & 59 \\
\hline & & RLd & 45 & 50 & $\mathrm{~s}$ & & $\mathrm{~m}$ & & $\mathrm{mp}$ & & 0 a 15 & 3 & 3 & 3 & 37 \\
\hline & & & 40 & & & & $\mathrm{~m}$ & & $\mathrm{mp}$ & & 0 a 10 & 3 & 2 & 3 & 43 \\
\hline$(868)$ & FODA & & 14 & & & $\mathrm{n}$ & $\mathrm{p}$ & $\mathrm{n}$ & $\mathrm{a}$ & $\mathrm{a}$ & 0 a 10 & 1 & 2 & 2 & 48 \\
\hline & FUDA & & 44 & & & $\mathrm{n}$ & $\mathrm{m}$ & $\mathrm{r}$ & $\mathrm{mp}$ & $\mathrm{a}$ & 0 a 30 & 3 & 3 & 3 & 93 \\
\hline & & & 25 & & & $\mathrm{~m}$ & & $\mathrm{p}$ & $\mathrm{a}$ & $\mathrm{a}$ & 0 a 10 & 1 & 2 & 2 & 118 \\
\hline & & & 55 & & & $\mathrm{p}$ & & $\mathrm{m}$ & $\mathrm{pp}$ & $\mathrm{mp}$ & 0 a 10 & 5 & 2 & 4 & 115 \\
\hline & $\mathrm{RV}$ & RLi & 35 & 25 & $\mathrm{v}$ & $\mathrm{p}$ & $\mathrm{n}$ & $\mathrm{n}$ & $\mathrm{pp}$ & $\mathrm{a}$ & 0 a 20 & 2 & 4 & 3 & 67 \\
\hline & & & 35 & & & $\mathrm{r}$ & & $\mathrm{m}$ & $\mathrm{pp}$ & $\mathrm{mp}$ & 0 a 25 & 5 & 5 & 5 & 455 \\
\hline & & & 11 & & & $\mathrm{p}$ & & $\mathrm{n}$ & $\mathrm{a}$ & $\mathrm{a}$ & 0 a 10 & 1 & 2 & 2 & 63 \\
\hline & & & 15 & & & $\mathrm{r}$ & & $\mathrm{n}$ & $\mathrm{a}$ & $\mathrm{a}$ & 0 a 10 & 1 & 2 & 2 & 34 \\
\hline & & & 3 & & & $\mathrm{r}$ & & $\mathrm{n}$ & $\mathrm{a}$ & $\mathrm{a}$ & 0 & 1 & 1 & 1 & 120 \\
\hline & & & 10 & & & $\mathrm{r}$ & & $\mathrm{n}$ & $\mathrm{a}$ & $\mathrm{a}$ & 0 a 5 & 1 & 1 & 1 & 95 \\
\hline & & & 30 & & & $\mathrm{p}$ & & $\mathrm{p}$ & $\mathrm{a}$ & $\mathrm{pp}$ & 0 a 20 & 4 & 4 & 4 & 31 \\
\hline & & & 60 & & & $\mathrm{p}$ & & $\mathrm{m}$ & $\mathrm{pp}$ & $\mathrm{mp}$ & 0 a 20 & 5 & 4 & 5 & 21 \\
\hline & & & 14 & & & $\mathrm{p}$ & & $\mathrm{n}$ & $\mathrm{a}$ & $\mathrm{a}$ & 0 a 10 & 1 & 2 & 2 & 95 \\
\hline 3 & $\mathrm{RV}$ & RLi & 56 & 25 & $\mathrm{~N}$ & $\mathrm{n}$ & $\mathrm{n}$ & $\mathrm{m}$ & $\mathrm{pp}$ & $\mathrm{mp}$ & 0 a 20 & 5 & 4 & 5 & 44 \\
\hline (711) & KV & KL1 & 15 & 25 & $\mathrm{~V}$ & $\mathrm{p}$ & & $\mathrm{n}$ & $\mathrm{a}$ & $\mathrm{a}$ & 0 a 5 & 1 & 1 & 1 & 40 \\
\hline & & & 51 & & & $\mathrm{~m}$ & & $\mathrm{n}$ & $\mathrm{pp}$ & $\mathrm{mp}$ & 0 a 30 & 5 & 5 & 5 & 43 \\
\hline & & & 30 & & & $\mathrm{p}$ & & $\mathrm{r}$ & $\mathrm{pp}$ & $\mathrm{a}$ & 0 a 25 & 2 & 5 & 4 & 51 \\
\hline & & & 65 & & & $\mathrm{~m}$ & & $\mathrm{n}$ & $\mathrm{pp}$ & $\mathrm{a}$ & 0 a 30 & 2 & 5 & 4 & 60 \\
\hline & & & 26 & & & $\mathrm{~m}$ & & $r$ & $\mathrm{pp}$ & $\mathrm{a}$ & 0 a 20 & 2 & 4 & 3 & 27 \\
\hline & & & 52 & & & $\mathrm{~m}$ & & $\mathrm{r}$ & $\mathrm{pp}$ & $\mathrm{a}$ & 0 a 30 & 2 & 5 & 4 & 42 \\
\hline & & & 20 & & & $\mathrm{r}$ & & $\mathrm{p}$ & pp & $\mathrm{a}$ & 0 a 10 & 2 & 2 & 2 & 95 \\
\hline
\end{tabular}




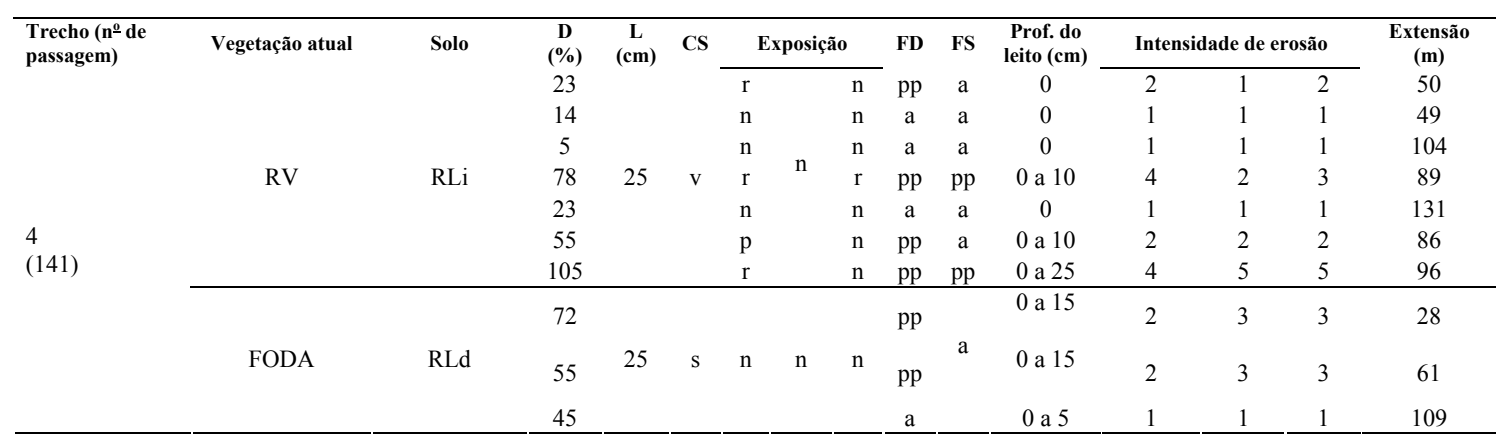

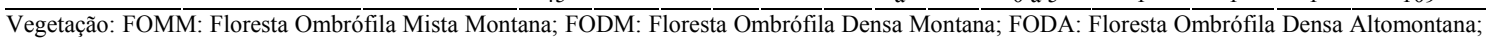
FODA (SSInt): Floresta Ombrófila Densa Altomontana (Sucessão secundária intermediária); FODA (SSI): Floresta Ombrófila Densa Altomontana (Sucessão secundária inicial), RV: Refúgio Vegetacional; Solo: CXvd lítico: Cambissolo Háplico Ta Distrófico lítico, CXvd léptico: Cambissolo Háplico Ta Distrófico léptico, RLh: Neossolo Litólico Húmico típico, RLd: Neossolo Litólico Distrófico típico, RLi; Neossolo Litólico Hístico típico, D: declividade; L: largura da trilha; CS: cobertura do solo na trilha: s: serrapilheira, v - vegetação; Exposição: So: solo, Ra: raiz, Ro: rocha, n: nenhuma, r: rara, p: pouca, m: muita; FD: formação de degraus: a: ausente, pp: pouco presente, mp: muito presente; FS: formação de sulcos: a: ausente, pp: pouco presente, mp: muito presente; Intensidade de erosão (valor): 1: muito baixa, 2: baixa, 3: média, 4 alta, 5: muito alta.

Trecho 01 da trilha para os picos Camapuã e Tucum

Esse trecho apresentou a maior intensidade de uso, com o número de passagens de visitantes estimado igual a 1023. Nesse trecho ocorrem três formações florestais, a Floresta Ombrófila Mista Montana sobre o Cambissolo Háplico Ta Distrófico lítico, a Floresta Ombrófila Densa Montana sobre o Cambissolo Háplico Ta Distrófico léptico e sobre o Neossolo Litólico Húmico típico e a Floresta Ombrófila Densa Altomontana (nas fases inicial e intermediária da sucessão secundária) sobre o Neossolo Litólico Húmico típico e sobre o Neossolo Litólico Distrófico típico. A declividade variou de 1 a 35\%, sendo predominante uma declividade de $15 \%$.

Apesar do maior pisoteio, não houve exposição do solo no leito da trilha, entretanto houve rara exposição de raízes das árvores e rochas (1 a $10 \%$ da extensão desse trecho apresentou raízes e rochas expostas) (Tabela 3). O fato de não haver solo exposto no leito da trilha se explica pela queda contínua de folhas das árvores, independemente da formação vegetal, porém não houve o acúmulo das folhas devido ao pisoteio constante, permanecendo uma fina camada de serapilheira, com aproximadamente $1 \mathrm{~cm}$ de espessura. A exposição rara de raízes se deve ao distanciamento entre as árvores, conseqüentemente havendo raras raízes sob a trilha, as quais ficaram expostas devido ao pisoteio. Houve rara exposição de rocha porque nesses pontos as rochas estavam mais próximas da superfície e ficaram expostas em conseqüência do pisoteio.

A largura média da trilha nesse trecho foi de $50 \mathrm{~cm}$, devido à passagem dos visitantes, não havendo valores muito maiores ou menores que esse. A profundidade do leito da trilha variou de 0 a 50 cm (Tabela 3). Observa-se que o Neossolo Litólico Húmico típico e o Neossolo Litólico Distrófico típico, sob a sucessão secundária da Floresta Ombrófila Densa Altomontana, apresentaram uma profundidade de até $50 \mathrm{~cm}$, na declividade de $35 \%$, enquanto que Cambissolo Háplico Ta Distrófico léptico apresentou uma profundidade de até $15 \mathrm{~cm}$ (Tabela 3). Essa diferença se deve possivelmente ao solo, pois o Cambissolo possui menor quantidade de argila e maior quantidade de carbono orgânico (Tabela 4), propriedades que proporcionam uma maior estruturação do solo e conseqüentemente maior resistência ao pisoteio, resultando em uma menor compactação e uma maior permeabilidade do solo, com conseqüente diminuição do escoamento superficial (MAGRO, 1999). De acordo com Cole (1993), solos com teores médios de argila e matéria orgânica e maior profundidade e fertilidade (saturação por bases) apresentam maior resistência ao pisoteio, que é o caso do Cambissolo Háplico Ta Distrófico léptico em relação aos outros solos (Tabela 4). Devido a essas características, esse solo não apresentou a formação de degraus ou sulcos nessa declividade. Entretanto o Neossolo Litólico Húmico típico apresentou formação de degraus (muito presente) na declividade de $23 \%$ e formação de sulcos (pouco presente) na declividade de $35 \%$, enquanto que o Neossolo Litólico Distrófico típico, na declividade de 34\%, apresentou apenas a formação de degraus, muito presente (Tabela 3). Observa-se que este solo possui uma quantidade ligeiramente maior de matéria orgânica que o Neossolo Litólico Húmico típico (Tabela 4), sendo, conseqüentemente mais permeável. Além de possuir menor quantidade de carbono, o Neossolo Litólico Húmico típico está localizado no fundo de vale, local com maior concentração de enxurrada, o que pode justificar sua maior degradação. 
Portanto, no Cambissolo Háplico Ta Distrófico léptico, a intensidade de erosão foi classificada de muito baixa a baixa, nas declividades de 10 e $35 \%$ com profundidade de 0 a $5 \mathrm{~cm}$ e de 0 a $15 \mathrm{~cm}$, respectivamente, enquanto que o Neossolo Litólico Húmico típico com a mesma variação de declividade mostrou-se mais suscetível, sendo que a intensidade de erosão foi classificada como muito baixa na declividade entre 0 e $19 \%$, com profundidade de 0 a $5 \mathrm{~cm}$, de baixa a muito baixa na declividade de $23 \%$, com formação de degraus, e muito alta na declividade de $35 \%$, com formação de degraus e de sulcos chegando a $50 \mathrm{~cm}$ de profundidade. No Neossolo Litólico Distrófico típico, na declividade de 4\%, a intensidade de erosão foi classificada como média, e como alta em 34\% de declividade, havendo a formação de degraus com $50 \mathrm{~cm}$ de profundidade (Tabela 3 ).

Trecho 02 da trilha para os picos Camapuã e Tucum

O trecho 02 apresentou uma intensidade de uso igual a 868 passagens, sendo a maior declividade igual a 70\%. Esse trecho passa pela Floresta Ombrófila Densa Altomontana (a maior parte está na fase intermediária da sucessão secundária) e pelo Refúgio Vegetacional, que estão sobre o Neossolo Litólico Distrófico típico e sobre a associação do Neossolo Litólico Hístico típico com afloramento de rocha, respectivamente. A profundidade do leito da trilha variou de 0 a $50 \mathrm{~cm}$, com declividades de 3 a $70 \%$. A largura da trilha sob a floresta foi de $50 \mathrm{~cm}$, enquanto que sob o refúgio foi de $25 \mathrm{~cm}$ (Tabela 3).

Sob a Floresta Ombrófila Densa Altomontana (mesmo na sucessão secundária), não ocorreu a exposição de solo ou de rocha no leito da trilha, porém constatou-se muita exposição de raízes $(>50 \%$ da extensão) (Tabela 3). Não houve a exposição de solo sob o leito da trilha devido à queda constante de folhas das árvores. Essa exposição de raízes, muito presente, deve-se à intensidade de uso, à declividade e à vegetação, pois a Floresta Ombrófila Densa Altomontana caracteriza-se por possuir um estrato arbóreo de até $10 \mathrm{~m}$ de altura, no qual as árvores crescem muito próximas e suas raízes se entrelaçam, o que não acontece na sucessão secundária, onde o entrelaçamento não é tão intenso, pois o número de árvores é menor (VASHCHENKO, 2006). Nesse trecho, o pisoteio constante causou a exposição das raízes, formando degraus, que se intensificam com o aumento da declividade. Essa situação dificulta o escoamento superficial da enxurrada, não ocorrendo, então, a formação de sulcos (TROEH, 1999).

O Refúgio Vegetacional caracteriza-se por plantas herbáceas de até $50 \mathrm{~cm}$ de altura, apresentando bromeliáceas e arbustos isolados. Sob essa vegetação não há a formação de serapilheira, diferente do que ocorre sob floresta (VASHCHENKO, 2006). Por esse motivo não se observa a exposição de raízes, pois se consideraram apenas raízes de espécies arbóreas. Porém, observa-se a exposição de solo, que se intensifica com o aumento da declividade e se deve à eliminação da cobertura vegetal causada pelo pisoteio (MAGRO, 1999). A exposição de rocha é conseqüência da formação de sulcos, cuja profundidade é igual à espessura do solo, causada pela enxurrada que se concentra no leito da trilha, a qual tem seu volume e sua velocidade aumentados com o aumento da declividade.

Os segmentos de maior declividade (35 e 55\%) apresentaram formação de sulcos muito presente, com muita exposição de rocha e pouca ou rara exposição de solo, com formação de degraus pouco presente e espessuras de 0 a $10 \mathrm{~cm}$ e 0 a $25 \mathrm{~cm}$, respectivamente (Tabela 3). Isso significa que nesses segmentos prevaleceram sulcos e estes chegaram à rocha, formando alguns degraus, devido à disposição das rochas, enquanto que a pouca ou rara exposição de solo aponta o remanescente do mesmo e sobre este ocorre a formação de degraus ou sulcos.

A exposição de rocha não ocorreu em todo o segmento por causa do microrrelevo e da sinuosidade da trilha, que alteram ou anulam a ação da enxurrada, observando-se, portanto, pontos com solo exposto ou coberto pela vegetação ou, ainda, com a formação de degraus ou sulcos. 


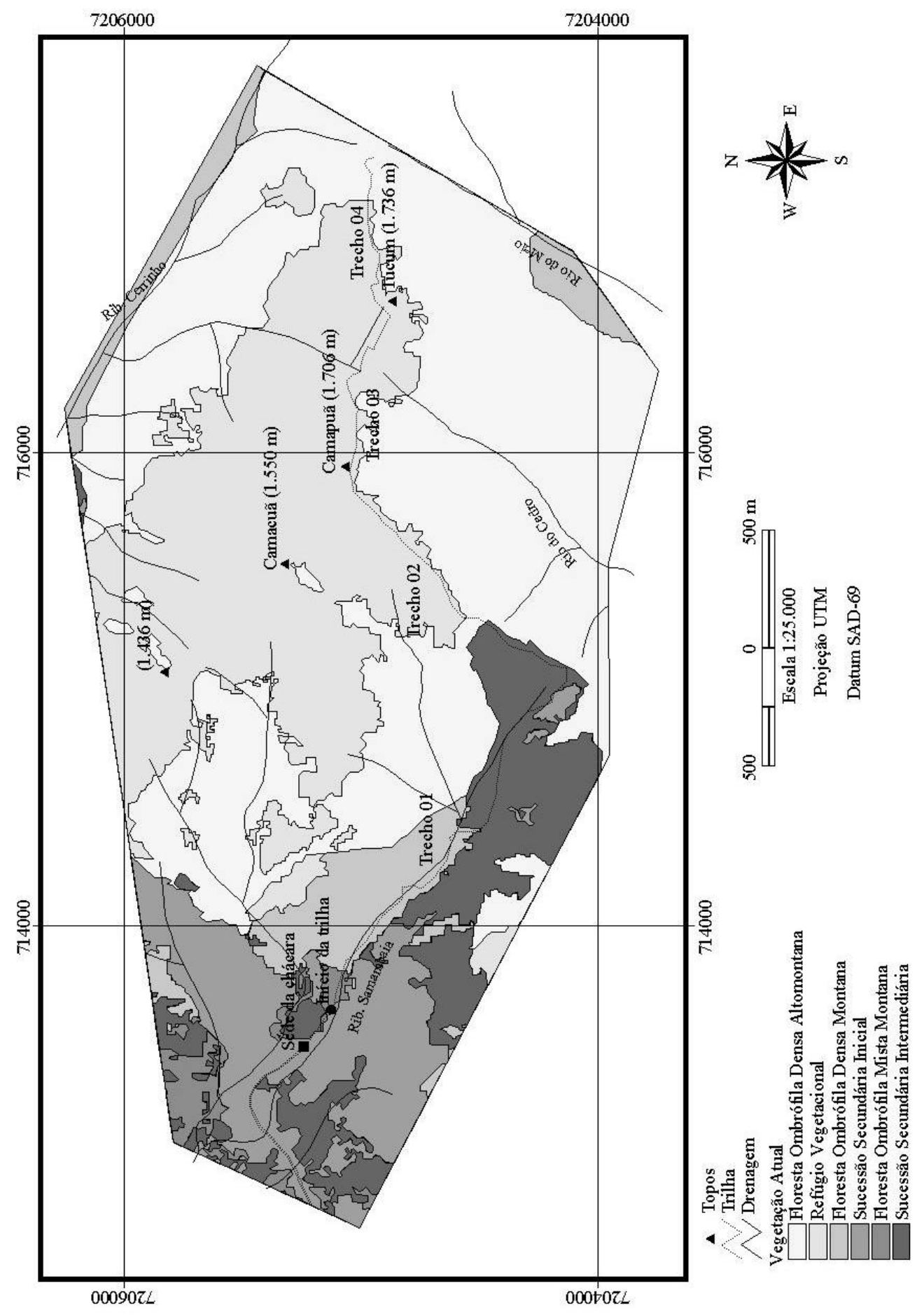

Figura 2. Localização da trilha e vegetação atual dos picos Camapuã e Tucum.

Figure 2. Localization of the trail and actual vegetation of the Camapuã and Tucum peaks. 
Tabela 4. Teores de areia, argila, silte, carbono (C) orgânico, matéria orgânica e saturação por bases em cada horizonte dos solos da trilha para os picos Camapuã e Tucum.

Table 4. Sand, clay, silte content, organic carbon, organic matter and base saturation for each soil horizons of the trail to the Camapuã and Tucum peaks.

\begin{tabular}{|c|c|c|c|c|c|c|c|c|}
\hline \multirow{2}{*}{ Horizonte } & \multirow{2}{*}{$\begin{array}{l}\text { Profundidade } \\
\text { (cm) }\end{array}$} & \multicolumn{4}{|c|}{$\begin{array}{l}\text { Composição granulométrica da terra fina } \\
\qquad\left(\mathrm{g} \mathrm{kg}^{-1}\right)\end{array}$} & \multirow{2}{*}{$\begin{array}{c}\text { Carbono } \\
\text { orgânico } \\
\mathbf{g ~ k g}^{-1}\end{array}$} & \multirow{2}{*}{$\begin{array}{c}\text { Matéria } \\
\text { orgânica } \\
\mathbf{g ~ k g}^{-1}\end{array}$} & \multirow{2}{*}{$\begin{array}{c}\text { Saturação } \\
\text { por bases } \\
(V \%)\end{array}$} \\
\hline & & $\begin{array}{l}\text { Areia } \\
\text { grossa }\end{array}$ & $\begin{array}{c}\text { Areia } \\
\text { fina }\end{array}$ & Argila & Silte & & & \\
\hline \multicolumn{9}{|c|}{ Perfil 01 - Cambissolo Háplico Ta Distrófico lítico } \\
\hline A & $0-10$ & 420 & 80 & 330 & 170 & 27,53 & 47,3 & 14,85 \\
\hline $\mathrm{Bi}$ & $10-20$ & 410 & 90 & 350 & 150 & 21,60 & 37,1 & 17,32 \\
\hline $\mathrm{C}$ & $20-40$ & 400 & 100 & 330 & 170 & 12,12 & 21,2 & 16,97 \\
\hline \multicolumn{9}{|c|}{ Perfil 02 - Neossolo Litólico Húmico típico } \\
\hline Oo & $2-0$ & - & - & - & - & - & - & - \\
\hline A & $0-20$ & 520 & 100 & 250 & 130 & 37,34 & 64,2 & 27,86 \\
\hline \multicolumn{9}{|c|}{ Perfil 03 - Cambissolo Háplico Ta Distrófico léptico } \\
\hline Oo & $10-0$ & - & - & - & - & - & - & - \\
\hline A & $0-17$ & 450 & 90 & 180 & 270 & 75,00 & 129 & 37,81 \\
\hline $\mathrm{Bi}$ & $17-34$ & 390 & 80 & 270 & 260 & 40,36 & 69,5 & 24,52 \\
\hline $\mathrm{C}$ & $34-55$ & 520 & 70 & 20 & 210 & 26,63 & 45,7 & 16,47 \\
\hline \multicolumn{9}{|c|}{ Perfil 04 - Neossolo Litólico Húmico típico } \\
\hline Oo & $5-0$ & - & - & - & - & - & - & - \\
\hline A & $0-23$ & 490 & 40 & 230 & 240 & 56,66 & 97,5 & 11,73 \\
\hline \multicolumn{9}{|c|}{ Perfil 05 - Neossolo Litólico Distrófico típico } \\
\hline Oo & $10-0$ & - & - & - & - & - & - & - \\
\hline A & $0-10$ & 510 & 30 & 250 & 210 & 70,94 & 122,02 & 3,3 \\
\hline \multicolumn{9}{|c|}{ Perfil 06 - Neossolo Litólico Hístico típico } \\
\hline Od & $0-14$ & 530 & 50 & 30 & 380 & 149,74 & 257,5 & 5,06 \\
\hline
\end{tabular}

Assim, a intensidade de erosão nesse solo, até 25\% de declividade, foi classificada como baixa, sendo a profundidade do leito da trilha de $10 \mathrm{~cm}$, porém, a partir dos $35 \%$ de declive, a erosão foi classificada como muito alta, apresentando sulcos e degraus com $25 \mathrm{~cm}$ de profundidade, sendo esta a situação mais grave, quando comparada com os outros solos encontrados na mesma declividade no trecho 01. No Neossolo Litólico Distrófico típico a intensidade de erosão foi classificada como baixa até $14 \%$ de declividade, e nas declividades entre 35 e $70 \%$ a erosão foi classificada como alta. Não houve a formação de sulcos, porém houve a formação de degraus a partir dos $35 \%$ de declividade (Tabela 3 ).

Trecho 03 da trilha para os Picos Camapuã e Tucum

O trecho 03 passa apenas pelo Refúgio Vegetacional, sobre a associação do Neossolo Litólico Hístico típico com afloramento de rocha, com declividade variando de 0 a $65 \%$ e número de passagens igual a 711. A largura da trilha foi de $25 \mathrm{~cm}$, e a profundidade variou de 0 a $30 \mathrm{~cm}$, sendo predominante de 0 a $10 \mathrm{~cm}$ (Tabela 3 ).

Nesse trecho, observa-se muita exposição do solo e de rocha nas maiores declividades, enquanto que nas menores declividades não houve exposição de solo, raízes ou rocha (Tabela 3). A exposição de rocha se deve à pequena espessura do solo onde houve a formação de sulcos, enquanto que a exposição de solos se deve à eliminação da cobertura vegetal pelo pisoteio, a qual é mais acentuada com o aumento da declividade, como observou Magro (1999). O aumento da declividade proporciona a formação de degraus pelo pisoteio e a formação de sulcos e aumento da profundidade devido à concentração da enxurrada sobre o solo sem cobertura vegetal.

Observa-se uma variação das condições do leito (profundidade do leito, formação de degraus e 
sulcos, exposição de solo e rocha), quando comparam-se segmentos com a mesma declividade. Isso se deve ao solo, como já descrito anteriormente, pois além de possuir alto teor de carbono orgânico e baixa quantidade de argila, possui muita variação na densidade aparente (de 0,2 a $0,9 \mathrm{Mg} \mathrm{kg}^{-1}$ ), sendo a média igual a $0,6 \mathrm{Mg} \mathrm{kg}^{-1}$ fora da trilha e $0,8 \mathrm{Mg} \mathrm{kg}^{-1}$ na trilha (observa-se que nesse trecho a densidade aparente é maior que no trecho 02), e muita variação na espessura, sendo as maiores densidades encontradas nas maiores espessuras (VASHCHENKO, 2006). Nesses pontos, a resistência ao pisoteio e à ação das enxurradas é maior.

Com relação à intensidade de erosão, observou-se que até $10 \%$ de declividade ela foi classificada como muito baixa, com crescimento de plantas sobre o leito da trilha e rara exposição de solo. Já entre 14 e $20 \%$ a intensidade de erosão foi baixa, ocorrendo a formação de degraus, que chegaram a uma profundidade do leito de até $10 \mathrm{~cm}$. Nos $26 \%$ de declividade, a intensidade de erosão foi classificada como média, ocorrendo a formação de degraus. A partir 30\% de declividade, a intensidade de erosão foi classificada como muito alta, ocorrendo a formação de sulcos e degraus (Tabela 3 ).

Comparando esse trecho com o trecho 02 , verifica-se no trecho 03 uma maior exposição de solo, maior formação de degraus, menor formação de sulcos e menor exposição de rocha. Dessa forma, constata-se que o solo, nesse trecho, sofreu um menor impacto. O que pode explicar isso, como observou Cole (1995), é a menor intensidade de uso (711 x 868 passagens) aliada à maior densidade aparente do solo.

Nesses dois trechos, nas menores declividades localizadas nas maiores altitudes, observou-se a vegetação crescendo sobre a trilha. Nesses pontos, a densidade aparente do solo é menor, e, conseqüentemente, a quantidade de matéria orgânica é maior, o que possivelmente absorve mais o impacto do pisoteio, não havendo, portanto, a eliminação da vegetação e nem o deslocamento do solo pelo pisoteio, o que poderia fragmentar a matéria orgânica e aumentar a densidade do solo, como se observa nas maiores declividades (MAGRO, 1999).

Trecho 04 da trilha para os picos Camapuã e Tucum

O trecho 04 passa pelo Refúgio Vegetacional e pela Floresta Ombrófila Densa Altomontana, os quais estão sobre a associação do Neossolo Litólico Hístico típico com afloramento de rocha e sobre Neossolo Litólico Distrófico típico, respectivamente. Esse trecho da trilha apresentou a menor intensidade de uso (141 passagens) e as maiores declividades, chegando a $105 \%$, sendo que a largura da trilha foi de $25 \mathrm{~cm}$ (Tabela 3).

A baixa intensidade de uso nesse trecho permite o crescimento da vegetação na trilha, sob o Refúgio Vegetacional, e o acúmulo de serapilheira sob a Floresta Ombrófila Densa Altomontana. Portanto, nesse trecho os solos são mais protegidos contra a erosão que os solos nos outros trechos $(01,02$ e 03), porém nas maiores declividades, sob o Refúgio Vegetacional, observam-se rara exposição de solo, aprofundamento do leito até $25 \mathrm{~cm}$, formação de degraus e de sulcos pouco presente (Tabela 3), devido, provavelmente, à concentração e à velocidade da enxurrada nesses pontos da trilha, embora o pisoteio tenha iniciado o processo, formando o traçado da trilha. Já na Floresta Ombrófila Densa Altomontana, a serapilheira protege muito bem o solo, não havendo exposição de solo, raízes ou rochas, apenas a formação de degraus (pouco presente), em que a profundidade chega a $15 \mathrm{~cm}$.

No Neossolo Litólico Hístico típico, a intensidade de erosão até os $5 \%$ de declividade foi classificada como muito baixa, e de 5 a $23 \%$ foi classificada como baixa. Nesta situação não se constatou a exposição do solo e nem o aprofundamento do leito. Observou-se um crescimento normal das plantas, havendo apenas uma marca de passagem, caracterizada por plantas amassadas. Já na declividade de $55 \%$ apareceu a formação de degraus, chegando até $10 \mathrm{~cm}$ de profundidade, sendo a intensidade de erosão classificada como média. A partir dos $78 \%$ de declividade ocorreu a formação de sulcos, com profundidade de $10 \mathrm{~cm}$, havendo a exposição de solo. Nessa declividade, a intensidade de erosão foi classificada como alta. A intensidade de erosão foi classificada como muito alta na declividade de $105 \%$, pois houve a formação de degraus e sulcos com profundidade de $25 \mathrm{~cm}$, porém não ocorrendo a exposição de rocha. No Neossolo Litólico Distrófico típico, na declividade de $45 \%$, a profundidade do leito da trilha chegou a $5 \mathrm{~cm}$, e a intensidade de erosão foi classificada como muito baixa. A partir dos $55 \%$ de declive houve a formação de degraus, e a profundidade do leito chegou a $15 \mathrm{~cm}$. Nessa condição, a intensidade de erosão foi classificada como média (Tabela 3). 
Comparação entre os trechos da trilha para os picos Camapuã e Tucum

Ao comparar os resultados encontrados no trecho 04 com os trechos avaliados anteriormente $(01$, 02 e 03), percebe-se nitidamente que quanto maior a intensidade de uso maior o impacto, como citaram Mcewen et al. (1996). Analisando os trechos 01 e 02 sob floresta, os quais apresentaram maior intensidade de uso (1023 e 868, respectivamente), observa-se que a largura da trilha foi de $50 \mathrm{~cm}$, a espessura média da cobertura do solo no leito pela serapilheira foi de $1 \mathrm{~cm}$ e houve a exposição de raízes, enquanto que no trecho 04 , com menor intensidade de uso (141 passagens), a largura da trilha foi de 25 $\mathrm{cm}$ e a espessura da cobertura do solo no leito pela serapilheira foi de $10 \mathrm{~cm}$, sendo que praticamente não houve a exposição de raízes. Ainda nesse sentido, observa-se que sob o Refúgio Vegetacional, nos trechos com maior intensidade de uso (trechos 02 e 03), houve maior exposição de solo e rocha. Essas observações confirmam a citação de Marion \& Merrian (1985) de que, devido ao uso intenso, a taxa de perda do horizonte orgânico pode exceder a deposição anual, havendo exposição de solo. Ao comparar o trecho 03 com o trecho 02 , considerando o mesmo solo, observou-se que, devido à intensidade de uso menor no trecho 03 em relação ao trecho 02 (711 x 868 passagens), houve a manutenção da vegetação na trilha nos pontos com declividade menor e ausência da exposição de rocha no leito da trilha, mesmo nas maiores declividades.

Numa análise geral, independentemente da intensidade de uso, constatou-se que quanto maior a declividade maior a perda de solo, caracterizada por uma maior profundidade do leito da trilha (Tabela 2). Yoda; Watanabe (2000), ao medirem a seção transversal da trilha, também observaram uma maior perda de solo conforme o aumento da declividade, o que também foi observado por Magro (1999).

Em relação à formação de degraus e sulcos, nos trechos 01 e 03, observou-se que nos locais mais íngremes a formação de degraus foi conseqüência de um pisoteio concentrado em alguns pontos na trilha, onde os caminhantes procuram firmar-se para não escorregarem. Constata-se ainda que a formação de degraus foi conseqüência principalmente do processo de compactação e do deslocamento do solo, devido ao pisoteio. Por outro lado, no trecho 02, sob a Floresta Ombrófila Densa Altomontana, não houve formação de sulcos, porém houve formação de degraus, provavelmente devido a esta formação florestal, que apresenta maior grau de proteção. Nesse tipo de vegetação, as árvores são de menor porte e crescem mais próximas umas das outras, existindo muitas raízes no solo, que, devido ao pisoteio constante, ficaram expostas, formando os degraus. Essa situação diminui consideravelmente o escorrimento da enxurrada, não havendo então a formação de sulcos. Sob o Refúgio Vegetacional, a formação de degraus foi conseqüência principalmente da exposição das rochas. Entretanto, no trecho 04, a formação de degraus e sulcos foi pouco presente e provavelmente ocorreu devido à enxurrada, pois o número de passagens de visitantes foi muito pequeno, apenas 141, e possivelmente teve pouca influência.

A formação de sulcos ocorreu nas maiores declividades, principalmente sob o Refúgio Vegetacional, onde ocorreu a eliminação da cobertura vegetal, pelo pisoteio, que favoreceu o escoamento superficial na trilha, o qual aumentou em volume e velocidade com o aumento da declividade.

Constata-se, portanto, que a erosão causada está diretamente relacionada com as características do local e com a intensidade de uso, observando-se, então, uma maior perda da cobertura vegetal e maior exposição de solo, raízes e rocha nos locais mais freqüentados, como citaram Mcewen et al. (1996).

\section{Relação entre intensidade de erosão e intensidade de uso, vegetação atual, solo e declividade}

$\mathrm{Na}$ tabela 5, podem ser observadas, resumidamente, quais as declividades encontradas em campo e suas respectivas intensidades de erosão, para cada classe de solo, formação vegetal e número de passagens (intensidade de uso). Nota-se que a intensidade de erosão é influenciada pela intensidade de uso, pela declividade, pelo solo e pela vegetação.

Ao comparar uma intensidade de uso em uma mesma declividade, verifica-se que no trecho 01, com 1023 passagens, na declividade de 35\%, as intensidades de erosão para os solos Cambissolo Háplico Ta Distrófico léptico, Neossolo Litólico Distrófico típico e Neossolo Litólico Húmico típico foram iguais a 2 (baixa), 4 (alta) e 5 (muito alta), respectivamente. Já no trecho 02, com 868 passagens, considerando a declividade de 35\%, observa-se que para o Neossolo Litólico Distrófico típico a intensidade de erosão é 4 (alta), enquanto que para o Neossolo Litólico Hístico típico é 5 (muito alta) (Tabela 5). Constata-se, portanto, que a intensidade de erosão aumenta conforme a ordem: Cambissolo Háplico Ta Distrófico léptico < Neossolo Litólico Distrófico típico < Neossolo Litólico Húmico típico < Neossolo Litólico Hístico típico, sendo a menor no Cambissolo Háplico Ta Distrófico léptico e a maior no Neossolo 
Litólico Hístico típico. Segundo Cole (1993), a maior vulnerabilidade dos solos à recreação (pisoteio) se deve ao maior teor de matéria orgânica e de argila, à menor profundidade e à menor fertilidade (saturação por bases), enquanto que solos com teores médios de argila e matéria orgânica e maior profundidade e fertilidade apresentam a menor vulnerabilidade. Nota-se que o Neossolo Litólico Hístico típico apresenta a menor profundidade e a maior quantidade de matéria orgânica, sendo, portanto, o mais vulnerável, enquanto que o Cambissolo Háplico Ta Distrófico léptico apresenta a maior profundidade, teores de matéria orgânica e argila médios e maior fertilidade em relação aos outros solos (Tabela 4), sendo, portanto, o menos vulnerável.

Tabela 5. Declividade (\%) observada em campo e respectiva intensidade de erosão para cada classe de solo, vegetação atual e número de passagens na trilha para os picos Camapuã e Tucum.

Table 5. Slope class (\%) observed and respective erosion intensity to each soil class, vegetation and passes number in the trail to the Camapuã and Tucum peaks.

\begin{tabular}{|c|c|c|c|c|c|c|c|}
\hline \multirow[b]{2}{*}{$\begin{array}{l}\text { Trecho } \\
\text { (número de } \\
\text { passagens) }\end{array}$} & \multirow[b]{2}{*}{ Vegetação atual } & \multirow[b]{2}{*}{ Solo } & \multicolumn{5}{|c|}{ Intensidade de erosão } \\
\hline & & & $\begin{array}{c}\text { Muito } \\
\text { baixa } \\
1\end{array}$ & $\begin{array}{c}\text { Baixa } \\
2\end{array}$ & $\begin{array}{c}\text { Média } \\
3\end{array}$ & $\begin{array}{c}\text { Alta } \\
4\end{array}$ & $\begin{array}{c}\text { Muito } \\
\text { alta } \\
5\end{array}$ \\
\hline \multirow{6}{*}{$\begin{array}{l}01 \\
(1023)\end{array}$} & $\begin{array}{c}\text { Floresta } \\
\text { Ombrófila Mista } \\
\text { Montana } \\
\end{array}$ & $\begin{array}{l}\text { Cambissolo Háplico } \\
\text { Ta Distrófico lítico }\end{array}$ & $12 \%$ & & & & \\
\hline & \multirow{2}{*}{$\begin{array}{c}\text { Floresta } \\
\text { Ombrófila Densa } \\
\text { Montana }\end{array}$} & $\begin{array}{l}\text { Cambissolo Háplico } \\
\text { Ta Distrófico léptico }\end{array}$ & $10 \%$ & $35 \%$ & & & \\
\hline & & $\begin{array}{l}\text { Neossolo Litólico } \\
\text { Húmico típico }\end{array}$ & 19 a $23 \%$ & & & & \\
\hline & \multirow{2}{*}{$\begin{array}{c}\text { Floresta } \\
\text { Ombrófila Densa } \\
\text { Altomontana } \\
\text { (sucessão } \\
\text { secundária } \\
\text { intermediária) } \\
\end{array}$} & $\begin{array}{l}\text { Neossolo Litólico } \\
\text { Distrófico típico }\end{array}$ & & & $4 \%$ & $34 \%$ & \\
\hline & & $\begin{array}{l}\text { Neossolo Litólico } \\
\text { Húmico típico }\end{array}$ & $1 \%$ & $23 \%$ & & & $35 \%$ \\
\hline & $\begin{array}{c}\text { Floresta } \\
\text { Ombrófila Densa } \\
\text { Altomontana } \\
\text { (sucessão } \\
\text { secundária } \\
\text { inicial) } \\
\end{array}$ & $\begin{array}{l}\text { Neossolo Litólico } \\
\text { Húmico típico }\end{array}$ & 0 a $17 \%$ & & & & \\
\hline \multirow{3}{*}{$\begin{array}{l}02 \\
(868)\end{array}$} & $\begin{array}{c}\text { Floresta } \\
\text { Ombrófila Densa } \\
\text { Altomontana } \\
\text { (sucessão } \\
\text { secundária } \\
\text { intermediária) }\end{array}$ & \multirow[t]{2}{*}{$\begin{array}{l}\text { Neossolo Litólico } \\
\text { Distrófico típico }\end{array}$} & & $3 \%$ & & 35 a $70 \%$ & \\
\hline & $\begin{array}{c}\text { Floresta } \\
\text { Ombrófila Densa } \\
\text { Altomontana } \\
\end{array}$ & & & $14 \%$ & & $44 \%$ & \\
\hline & $\begin{array}{c}\text { Refúgio } \\
\text { Vegetacional }\end{array}$ & $\begin{array}{l}\text { Neossolo Litólico } \\
\text { Hístico típico }\end{array}$ & & 11 a $25 \%$ & & & 35 a $55 \%$ \\
\hline $\begin{array}{l}03 \\
(711)\end{array}$ & $\begin{array}{c}\text { Refúgio } \\
\text { Vegetacional }\end{array}$ & $\begin{array}{l}\text { Neossolo Litólico } \\
\text { Hístico típico }\end{array}$ & 3 a $10 \%$ & 14 a $20 \%$ & $26 \%$ & & 30 a $65 \%$ \\
\hline \multirow{2}{*}{$\begin{array}{l}04 \\
(141)\end{array}$} & $\begin{array}{c}\text { Refúgio } \\
\text { Vegetacional }\end{array}$ & $\begin{array}{c}\text { Neossolo Litólico } \\
\text { Hístico típico }\end{array}$ & 5 a $14 \%$ & 23 a $55 \%$ & $78 \%$ & & $105 \%$ \\
\hline & $\begin{array}{c}\text { Floresta } \\
\text { Ombrófila Densa } \\
\text { Altomontana }\end{array}$ & $\begin{array}{l}\text { Neossolo Litólico } \\
\text { Distrófico típico }\end{array}$ & $45 \%$ & & 55 a $72 \%$ & & \\
\hline
\end{tabular}


Observando uma determinada intensidade de erosão, em uma mesma classe de solo, verifica-se que com a diminuição do número de passagem (intensidade de uso) esta mesma intensidade de erosão ocorre em pontos de maior declividade. A intensidade de erosão 3 (média) no Neossolo Litólico Distrófico típico, com 1023 passagens, ocorreu na declividade de 4\%, enquanto que, com 141 passagens, essa intensidade de erosão ocorreu na declividade de 55 a 72\%. Já no Neossolo Litólico Hístico típico a intensidade de erosão 5 (muito alta) ocorreu nas declividades de 35 a $55 \%$, 30 a $65 \%$ e $105 \%$, de acordo com os números de passagens 868, 711 e 141, respectivamente (Tabela 5). Portanto, quanto menor a intensidade de uso menor a intensidade de erosão. Cole (1995) fez a mesma constatação ao observar os efeitos do número de passagens de visitantes sobre a vegetação de uma trilha.

Em uma mesma classe de solo com uma mesma intensidade de uso, quanto maior a declividade, maior a intensidade de erosão, como observou Magro (1999). Para o Neossolo Litólico Húmico típico, com 1023 passagens, nas declividades de 0 a $19 \%, 23 \%$ e $35 \%$ as intensidades de erosão foram igual a 1 (muito baixa), 2 (baixa) e 5 (muita alta), respectivamente. Já para o Cambissolo Háplico Ta Distrófico léptico, nas declividades de $10 \%$ e $35 \%$, as intensidades de erosão foram 1 (muito baixa) e 2 (baixa), respectivamente (Tabela 5).

A ocorrência das maiores intensidades de erosão nas maiores declividades, como observado no presente trabalho (Tabela 5) pode ser explicada pela eliminação da cobertura vegetal, pelo selamento superficial causado pelas gotas da chuva e pela maior velocidade e volume da enxurrada, fatores que interferem no processo erosivo, conforme descrito por Cogo et al. (2003).

Devido aos dados encontrados (Tabelas 3 e 5), não foi possível estabelecer qual formação vegetal exerce maior efeito sobre a intensidade de erosão, pois, de maneira geral, sobre cada solo ocorre uma vegetação diferente. Além disso, não ocorrem as mesmas declividades. Porém, a influência da vegetação sobre a intensidade de erosão está na existência da primeira, que, se for eliminada, deixará o solo exposto à ação das chuvas e/ou enxurradas, pois se observou que, sob o Refúgio Vegetacional, onde houve a eliminação da vegetação pelo pisoteio, houve a formação de sulcos e até mesmo a exposição de rocha nas maiores declividades (Tabela 3). A eliminação da cobertura vegetal nas maiores declividades se deve, possivelmente, pela maior pressão exercida pelo pisoteio dos visitantes, pois foi observado que, no momento da descida, os caminhantes pisavam com maior força, devido à altura dos degraus ou porque desciam correndo. Essa maior força aplicada sobre o solo não contribuiu só para a eliminação da cobertura vegetal, mas também para a formação dos degraus.

Ainda nesse sentido, observou-se que, sob as florestas Ombrófila Mista Montana, Densa Montana, Densa Altomontana e sucessões secundárias, praticamente não há exposição de solo ou formação de sulcos (Tabela 3), pois elas fornecem cobertura ao solo (serapilheira) e criam obstáculos ao escoamento superficial, como cita Troeh et al. (1999), devido à própria existência das árvores e à exposição de raízes causada pelo pisoteio, situação bem visível sob a Floresta Ombrófila Densa Altomontana (trecho 02), a qual está associada à declividade.

Portanto, a intensidade de uso e a declividade exercem grande influência na proteção dos solos pela vegetação, sendo que quanto maior a intensidade de uso e a declividade, maior a intensidade de erosão sob uma mesma vegetação e sob um mesmo solo (Tabela 5).

\section{CONCLUSÕES}

Conforme os resultados obtidos, conclui-se que:

- A trilha passa por diferentes situações de vegetação, solo e declividade e apresenta formação de degraus e sulcos, exposição de solo, raízes e rocha, largura e profundidade que variam conforme a situação predominante.

- A trilha apresentou intensidades de uso diferentes, sendo o número de passagens de visitantes estimado em 1023, 868, 711 e 141 nos trechos 01, 02, 03 e 04, respectivamente.

- A intensidade de erosão varia em função da intensidade de uso, declividade, cobertura vegetal e classe de solo e foi classificada de muito baixa a muito alta.

- A intensidade de erosão aumentou com a intensidade de uso (número de passagens) e com a declividade. 
- A intensidade de erosão variou em função das classes de solo do local, sendo crescente conforme a seguinte seqüência: Cambissolo Háplico Ta Distrófico léptico < Neossolo Litólico Distrófico típico < Neossolo Litólico Húmico típico < Neossolo Litólico Hístico típico.

- Na trilha, a vegetação diminui a intensidade de erosão, porém esse efeito diminui com o aumento da intensidade de uso e da declividade.

\section{REFERÊNCIAS}

ANDRADE, W. J. de. Implantação e manejo de trilhas. In MITRAUD, S. Manual de ecoturismo de base comunitária: ferramentas para um planejamento responsável. Brasília: WWF. 2003. p. 247259.

Bigarella, J. J. A Serra do Mar e a Porção Oriental do Estado do Paraná. Curitiba: Secretaria Estadual de Planejamento/Associação de Defesa e Educação Ambiental. 1978. 248 p.

BARROS, M. I. A. Caracterização da visitação, dos visitantes e avaliação dos impactos ecológicos e recreativos do planalto do Parque Nacional do Itatiaia. Piracicaba, SP. 2003. 121 f. Dissertação (Mestrado em Recursos Florestais). Escola Superior de Agricultura Luiz de Queiroz, Universidade de São Paulo.

BRASIL. Represa do Capivari. 1971. 1 mapa: color. Escala 1:50.000.

COGO N. P.; LEVIEN R.; SCHWARZ R. A. Perdas de solo e água por erosão hídrica influenciadas por métodos de preparo, classes de declive e níveis de fertilidade do solo. Revista Brasileira de Ciência do Solo. n. 27. p. 743-753. 2003.

COLE, D. N. Minimizing conflict between recreation and nature. In SMITH D. S.; HELLMUND, P. C. Ecology of greenways: Design and function of linear conservation areas. Minneapolis, MN: University of Minnesota Press. p. 105-122. 1993.

COLE, D. N. Recreational trampling experiments: effects of trampler weight and shoe type. Res. Pap. INT-RN-425. Ogden, UT: U.S. Department of Agriculture, Forest Service, Intermountain Research Station. 4 p. 1995.

EMBRAPA: Empresa Brasileira de Pesquisas Agropecuárias. Sistema brasileiro de classificação de solos. Rio de Janeiro: Centro Nacional de Pesquisa de Solos. 1999. 412 p.

IAPAR - INSTITUTO AGRONÔMICO DO PARANÁ. Cartas Climáticas do Estado do Paraná, 1994. Londrina: Instituto Agronômico do Paraná. 1994. 49 p.

IBGE: INSTITUTO BRASILEIRO DE GEOGRAFIA E ESTATÍSTICA. Morretes. 1992a. 1 mapa: color. Escala 1:50.000.

IBGE: INSTITUTO BRASILEIRO DE GEOGRAFIA E ESTATÍSTICA. Manual téenico da vegetação brasileira. Rio de Janeiro: Diretoria de Geociências. Departamento de Recursos Naturais e Estudos Ambientais. 1992b. 92 p.

MAGRO, T. C. Impactos do uso público em uma trilha no planalto do Parque Nacional do Itatiaia. São Carlos, SP. 1999. 135p. Tese (Doutorado em Ciências da Engenharia Ambiental). Escola de Engenharia de São Carlos, Universidade de São Paulo.

MARION, J. L.; MERRIAN, L. C. Predictability of recreational impact on soils. Soil Science Society of America Journal, Chicago, 49 v., n. 3, p. 751: 753. 1985.

MCEWEN, D.; COLE, D. N.; SIMON, M. Campsite impacts in four wildernesses in the SouthCentral United States. Res. Pap. INT-RP-490. Ogden, UT: U.S. Department of Agriculture, Forest Service, Intermountain Research Station. 12 p. 1996.

SEMA - Secretaria de Estado do Meio Ambiente e Recursos Hídricos. Diretrizes para uma política estadual de ecoturismo. Curitiba: Instituto Ambiental do Paraná - IAP. 1996. 
SEMA - SECRETARIA DE ESTADO DO MEIO AMBIENTE E RECURSOS HÍDRICOS. Resolução SEMA n ${ }^{\circ} 031$ de 24 de agosto de 1998, que dispõe sobre o licenciamento ambiental, autorização ambiental, autorização florestal e anuência prévia para desmembramento e parcelamento de gleba rural. Curitiba: Secretaria de Estado do Meio Ambiente e Recursos Hídricos. 1998.

SEMA - Secretaria de Estado do Meio Ambiente e Recursos Hídricos. Diretrizes para o turismo em áreas naturais no Estado do Paraná. Curitiba: Secretaria de Estado do Meio Ambiente e Recursos Hídricos. 2000 .

TROEH, F. R.; HOBBS, J. A.; DONAHUE, R. L. Soil and water conservation: productivity and environmental protection. 3 ed. New Jersey: Prentice-Hall, Inc. 1999. 610 p.

VASHCHENKO, Y. Caracterização da trilha e o impacto do montanhismo nos picos Camapuã e Tucum -Campina Grande do Sul: PR. Curitiba, PR. 2006. 96 p. Dissertação (Mestrado em Ciência do Solo). Setor de Ciências Agrárias, Universidade Federal do Paraná.

YODA, A.; WATANABE, T. Erosion of mountain hiking trail over a seven-year period in Daisetsuzan National Park, Central Hokkaido, Japan. USDA Forest Service Proceedings RMRS-P-15. v. 5. p. 172178. 2000. 